'Citizenship is man's basic right, for it is nothing less than the right to have rights.' Chief Justice Earl Warren, dissenting in Perez v Brownell, US Supreme Court (356 US 44 1958)

It is probable that Chief Justice Warren had read Hannah Arendt's groundbreaking study The Origins of Totalitarianism. Arendt coined the phrase 'the right to have rights', which encapsulated her insight that although human rights were held to be universal, access to those rights was impossible without citizenship of a nation state.

The relationship between a Government and its citizens, the obligations owed by the one to the other, and how and for what reasons Governments can end the relationship by revoking citizenship have become fraught questions in the post-9/11 age, when citizens' rights have repeatedly crashed against doctrines of state sovereignty. Some Muslim citizens of European states have discovered that they cannot rely on their government to protect them from arbitrary and illegal detention or torture abroad. Others have discovered how easy it is to lose citizenship, and how few procedural protections they have.

\section{The case of Ali Aarrass}

On 10th January 2014, lawyers appeared before the Brussels first-instance court to argue that Belgium is in breach of its obligation to protect its dual-national citizens from torture. The case is that of Ali Aarrass, a BelgianMoroccan citizen tortured and imprisoned in Morocco, to whom the Belgian government refuses to extend consular protection.

Born in the Spanish enclave of Melilla and educated in Belgium, where he did his military service, Ali was subjected to a two-year investigation for alleged involvement in arms smuggling by Spanish judge Baltasar Garzón, and was cleared in March 2009. The Spanish authorities nevertheless extradited him to Morocco in December 2010, despite a UN Human Rights Committee request to stay the extradition. Ali disappeared into incommunicado detention and nearly a year later was convicted in the Rabat court of smuggling arms and sentenced to 15 years' imprisonment (later reduced to 12). The conviction was based solely on 'confession' evidence which Ali consistently maintained was false, his signature to an incomprehensible document in an unfamiliar language obtained by sustained torture.

The allegations of torture were never properly investigated by the Moroccan authorities, but following a prison visit with a forensic medical expert in September 2012, UN Special Rapporteur Juan Mendez confirmed that Ali had been severely tortured. A December 2013 report from the UN's Working Group on Arbitrary Detention concurred that Ali's confession was obtained by torture, rendering his conviction and imprisonment unlawful.

\section{No help from Belgium}

During the whole period of his incarceration, Ali's family and supporters have called on the Belgian government to provide diplomatic
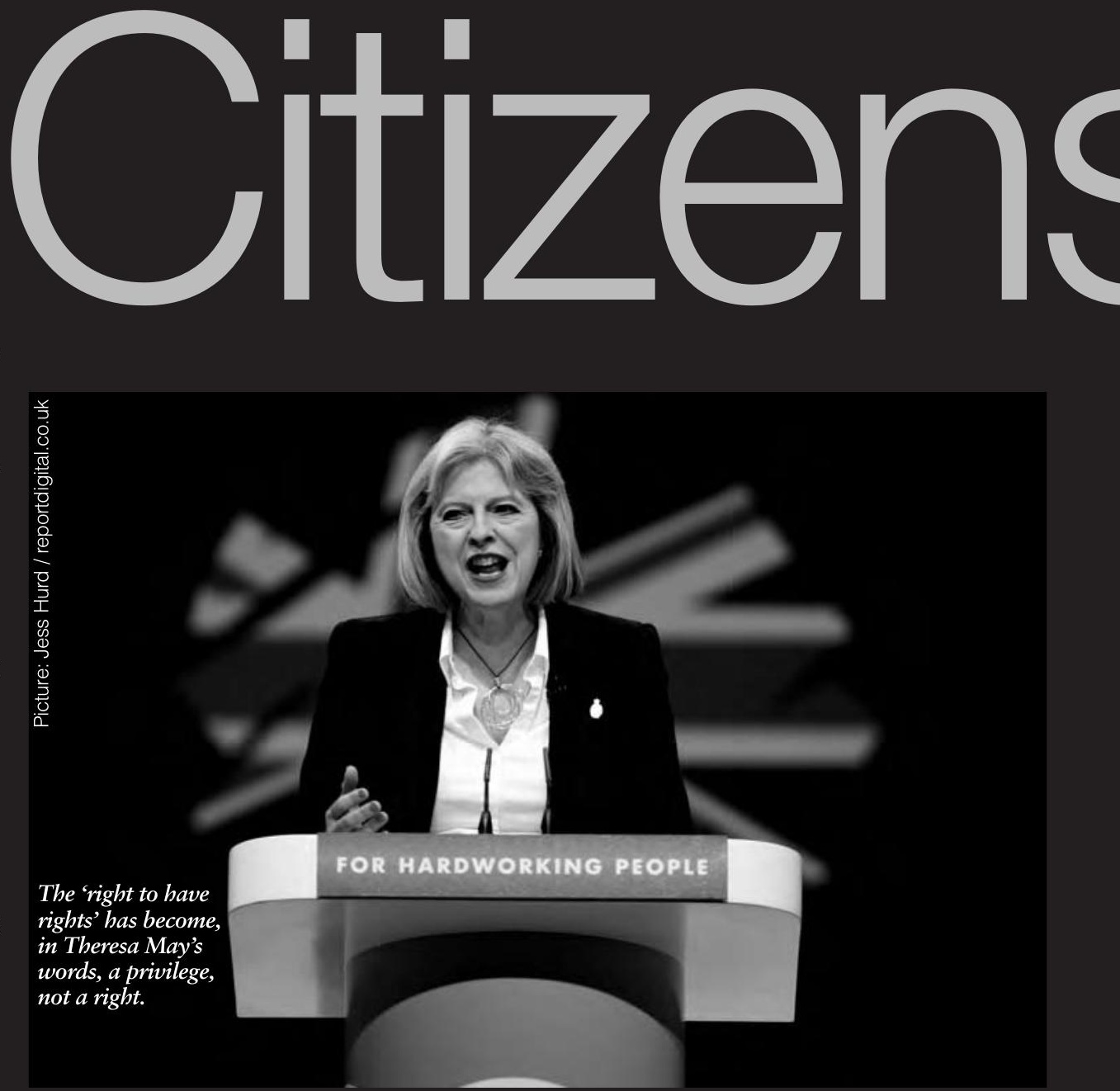

protection. The Foreign Minister has consistently refused, saying that in Morocco, Ali is a Moroccan citizen and it would be contrary to normal practice to intervene diplomatically. Only in August 2013, when Ali was in a critical condition on a hunger and thirst strike, did the Minister ask the Moroccan government to ensure that he was treated with respect for his human rights. Even then, he insisted that the Government was not providing diplomatic assistance and would not intervene in the conviction. The lawyers' argument is that since torture is jus cogens in international law, the obligation to protect citizens from torture must take precedence over diplomatic conventions of non-intervention.

\section{What is citizenship worth?}

Ali's case raises forcefully the issue of the way Muslim 'terror suspects' are treated as noncitizens by the states of their nationality, in the context of the clash between diplomatic conventions (reflecting State sovereignty) and human rights obligations.

Feroz Abbasi was one of the Muslim British citizens kidnapped abroad and bundled off to Guantánamo (others included Ruhel Ahmed, Tarek Dergoul, Jamal Al Harith, Shafiq Rasul, Asif Iqbal, Richard Belmar, Martin Mubanga and Moazzem Begg). In a challenge brought on behalf of Abbasi, $R$ (Abbasi) $v$ Secretary of State for Foreign and Commonwealth Affairs [2002] EWCA Civ 1598, the Court of Appeal accepted that at Guantanamo the men were 'arbitrarily detained in a "legal black-hole" without the possibility of challenging their detention, in apparent contravention of fundamental principles recognised by both jurisdictions and by international law' - but the Government denied any entitlement to consular protection against arbitrary and limitless detention - and the court agreed. 'International law has not yet recognised that a State is under a duty to intervene by diplomatic or other means to protect a citizen who is suffering or threatened with injury in a foreign State', the Court of Appeal said. The judges held that since the Foreign $\&$ Commonwealth Office (FCO) had already considered Mr Abbasi's request for assistance, there was nothing further they could do - they could not order the FCO to intervene on behalf of the Britons held at Guantánamo.

Relatives of Moazzem Begg and other British detainees sought to join Abbasi's case as interveners and to put evidence of their treatment before the court, but the application was refused, so there were no allegations of torture or inhuman treatment before the court, although by the time of the hearing in September 2002 the treatment of detainees (including British nationals) at Bagram and Guantánamo was already causing grave concern.

It is not only Muslims who find themselves abandoned by the country of their nationality in the face of ill-treatment by a foreign state. As recently as January 2014, the European Court of Human Rights in Jones and others $v$ United Kingdom [2014] ECHR 32, upheld the 
